\title{
In Vitro Propagation of Virginia Pine from Cotyledons
}

\author{
Carole H. Saravitz', Frank A. Blazich', and Henry V. Amerson ${ }^{3}$ \\ Department of Horticultural Science, North Carolina State University, Raleigh, NC 27695-7609 \\ Additional index words. Pinus virginiana, tissue culture, organogenesis, conifers, biotechnology, Christmas trees, \\ micropropagation
}

\begin{abstract}
Adventitious shoots developed on cotyledons of Virginia pine (Pinus virginiana Mill.) excised from seeds subjected to $\mathrm{H}_{2} \mathrm{O}_{2}$ treatment for 3 , 6, or 9 days and cultured on media containing 0.5 to $10 \mathrm{mg} \mathrm{BA} / \mathrm{liter}$. Shoot regeneration was greatest (42 shoots per embryo) on cotyledons from seeds treated with $\mathrm{H}_{2} \mathrm{O}_{2}$ for 6 days and placed on medium containing BA at $10 \mathrm{mg} \cdot$ liter $^{-1}$. Excised shoots elongated on medium lacking BA. Following elongation, shoots were placed on media containing IBA at 0 to $40 \mathrm{mg} \cdot$ liter $^{-1}$ for 14 days followed by transfer to the same medium lacking auxin. Without IBA treatment, rooting was 3\%, and increased to $50 \%$ for 5 to $40 \mathrm{mg} \cdot \mathrm{miter}^{-1}$. Rooted shoots averaged 2.0 roots per shoot without auxin incorporation, 3.3 roots when treated with $5 \mathrm{mg}$ IBA/liter, and the number of roots increased linearly with increased IBA concentration up to $40 \mathrm{mg}^{-l i t e r}{ }^{-1}(4.5$ roots $)$. Plantlets were transferred to growing medium and acclimated successfully to greenhouse conditions. Chemical names used: $N$ - (phenylmethyl)$1 \mathrm{H}$ - purine-6-amine (BA), $1 \mathrm{H}$ - indole-3-butyric acid CBA).
\end{abstract}

Virginia pine is an important Christmas tree species grown in the southeastern United States. Currently, the species is propagated exclusively by seed. However, variability among trees is a problem with sexual propagation. Development of asexual propagation procedures, such as rooting of stem cuttings, would be advantageous, allowing cloning of trees with desirable characteristics. Unfortunately, techniques for asexual propagation by stem cuttings have not been reported.

Another possibility for asexual propagation is tissue culture, using embryonic tissues as explants. Such procedures could lead to mass propagation from seeds of superior trees or families and provide a foundation for future studies aimed at in vitro propagation using vegetative tissues of trees in the adult growth phase.

Development of a successful protocol for in vitro propagation of Virginia pine from embryonic tissues appears feasible since many Pinus L. species have been propagated using this approach (Bonga and Durzan, 1987). However, the only published report (Brown and Sommer, 1977) dealing with tissue culture propagation of Virginia pine is a survey of in vitro regeneration of Pinus spp. and Douglas fir [Pseudotsuga menziesii (Mirb.) Franco]. This research showed that adventitious shoots could be induced on cotyledons of Virginia pine, although the number of shoots per embryo was not reported and the methodology used was not described fully. Therefore, our objective was to develop procedures for tissue culture propagation of Virginia pine using explants of cotyledons.

\section{Materials and Methods}

Explant source and seed germination. Seeds from a North Carolina stand of Virginia pine (exact provenance unknown)

Received for publication 10 May 1990. This research was funded by the North Carolina Agricultural Research Service (NCARS), Raleigh, NC 27695-7643. Use of trade names in this publication does not imply endorsement by the NCARS of products named nor criticism of similar ones not mentioned. Assistance of the North Carolina Forest Service is gratefully acknowledged. From a thesis submitted by C.H.S. in partial fulfillment of the requirements for the $\mathrm{PhD}$ degree. The cost of publishing this paper was defrayed in part by the payment of page charges. Under postal regulations, this paper therefore must be hereby marked advertisement solely to indicate this fact.

'Graduate Research Assistant.

${ }^{2}$ Professor.

${ }^{3}$ Associate Professor, Dept. of Forestry. were extracted from cones in Fall 1969 by the North Carolina Forest Service, dried to a moisture content of $6 \%$ to $6.5 \%$, and stored at $-13 \mathrm{C}$. Abnormal, damaged, and undersized seeds were removed before initiation of Expt. 1. Following removal from storage in Dec. 1987 and May 1988, seeds were nicked at the micropylar end with a scalpel and placed in $1 \%(\mathrm{v} / \mathrm{v})$ $\mathrm{H}_{2} \mathrm{O}_{2}$ for the first 3 days and $0.1 \%(\mathrm{v} / \mathrm{v}) \mathrm{H}_{2} \mathrm{O}_{2}$ thereafter. For germination, seeds were maintained at an 8/16-h thermoperiod of $30 / 20 \mathrm{C}$ and were irradiated during the 8 -h cycle with a combination of cool-white fluorescent and incandescent lamps. The lamps provided a photosynthetic photon flux [PPF (400-700 $\mathrm{nm})$ ] of $17.9 \mu \mathrm{mol} \cdot \mathrm{s}^{-1} \cdot \mathrm{m}^{-2}(1.3 \mathrm{klx})$. This and all other light measurements reported were recorded with a LI-COR LI 185A quantum/radiometer/photometer (LI-COR, Lincoln, Neb.).

Influence of $\mathrm{BA}$ concentration and duration of $\mathrm{H}_{2} \mathrm{O}_{2}$ treatment on shoot induction-Expt. 1. Following $\mathrm{H}_{2} \mathrm{O}_{2}$ treatment for 3, 6 , or 9 days, which accelerated germination, seeds were surfacesterilized with $70 \%(\mathrm{v} / \mathrm{v})$ ethanol for $2 \mathrm{~min}, 0.5 \%(\mathrm{w} / \mathrm{v}) \mathrm{Ca}(\mathrm{OCl})$ for $10 \mathrm{~min}$, and rinsed three times with sterile distilled water (a quick rinse, a 10-min soak, and another quick rinse). Embryos of the following approximate lengths were representative of $\mathrm{H}_{2} \mathrm{O}_{2}$ treatment for 3, 6, and 9 days, respectively: 4,5 , and 6-7 $\mathrm{mm}$. Cotyledons were aseptically excised and placed horizontally into $100 \times 25-\mathrm{mm}$ plastic petri dishes containing $25 \mathrm{ml}$ of shoot induction medium. Shoot induction medium consisted of a Brown and Lawrence (BLG) medium, as modified by Amerson et al. (1985), containing 3\% sucrose and $0.8 \%$ agar and supplemented with the following concentrations of BA: $0.5,1,5$, or 10 mg.liter ${ }^{-1}$. The $\mathrm{pH}$ of the media was adjusted to 5.5 before autoclaving. Explants remained on the initial medium for 2 weeks followed by transfer to $100 \times 25-\mathrm{mm}$ plastic petri dishes containing $25 \mathrm{ml}$ of secondary medium. Secondary medium consisted of full-strength Gresshoff and Doy (GD) medium, as modified by Mott and Amerson (1981), containing 2\% sucrose, $1 \%$ activated charcoal, and $0.8 \%$ agar. The $\mathrm{pH}$ of the medium was adjusted to 5.5 before autoclaving. Cotyledons remained on secondary medium for 8 weeks, including one transfer after 4 weeks. Cultures were maintained at 22C under continuous irradiation provided by a combination of cool-white fluorescent and incandescent lamps [PPF $(400-700 \mathrm{~nm})=49 \mu \mathrm{mol} \cdot \mathrm{s}^{-1} \cdot \mathrm{m}^{-2}$ (3.5 klx)].

The experimental design was a randomized complete block with a factorial arrangement of treatments (three durations of 
$\mathrm{H}_{2} \mathrm{O}_{2}$ treatment $\times$ four BA levels) and two replications. Each treatment combination consisted of six petri dishes containing cotyledons of four seeds. Due to contamination. some petri dishes were discarded, resulting in unbalanced data.

The number of shoots per embryo was recorded 10 weeks after the experiment was initiated. Means were calculated by petri dish and then by replication. Data were subjected to multiple regression analysis to determine relationships between duration of $\mathrm{H}_{2} \mathrm{O}_{2}$ treatment, $\mathrm{BA}$ concentration, and shoot induction.

Rooting of shoots and acclimation of plantlets-Expt. 2. Following recording of the number of shoots per embryo, shoots were excised and placed on secondary medium (described in Expt. 1) for further elongation. Shoots $\geq 1 \mathrm{~cm}$ were, placed vertically in $60 \times 20-\mathrm{mm}$ plastic petri dishes containing $10 \mathrm{ml}$ of a modified half-strength GD medium (described in Expt. 1) of $1 \%$ sucrose and $0.8 \%$ agar and supplemented with the following concentrations of IBA: $0,5,10,20$, or $40 \mathrm{mg} \cdot$ liter $^{-1}$. The $\mathrm{pH}$ of the media was adjusted to 5.5 before autoclaving. The experimental design was a randomized complete block with five IBA treatments and two replications. A replication consisted of 17 petri dishes for an IBA treatment, and each dish contained three shoots. After 14 days, shoots were transferred to the same medium lacking IBA. Shoots remained on medium lacking IBA for 8 weeks, including one transfer to fresh medium after 4 weeks. During rooting, cultures were maintained at $22 \mathrm{C}$ under a 12-h photoperiod provided by a combination of coolwhite fluorescent and incandescent lamps [PPF $(400-700 \mathrm{~nm})$ $\left.=37 \mu \mathrm{mol} \cdot \mathrm{s}^{-1} \cdot \mathrm{m}^{-2}(2.8 \mathrm{klx})\right]$.

Ten weeks after the experiment was initiated, we recorded the number of primary roots $\geq 1 \mathrm{~mm}$ in length. Any shoot having one or more roots was classified as rooted. Means were calculated by petri dish and then by replication. Data were subjected to regression analysis.

Following rooting, plantlets were transferred to 0.15 -liter plastic pots containing a sterile medium of 1 peat $: 1$ vermiculite $(\mathrm{v} /$ v). Initially, high humidity was maintained by misting the plantlets daily with water and enclosing them in sealed plastic bags. Plantlets were maintained at $22 \mathrm{C}$ under continuous irradiation provided by a combination of cool-white fluorescent and incandescent lamps [PPF $(400-700 \mu \mathrm{nm})=47 \mu \mathrm{mol} \cdot \mathrm{s}^{-1} \cdot \mathrm{m}^{-2}(3.3$ $\mathrm{klx})$ ]. Plantlets were gradually acclimated to lower humidity and transferred to a greenhouse. During acclimation, plantlets were fertilized twice weekly with half-strength Hoagland's solution (Hoagland and Arnon, 1950).

\section{Results}

After 2 weeks on shoot induction medium, cotyledons appeared swollen and meristematic areas were evident (Fig. 1A). During the 4 weeks following transfer to secondary medium, meristematic areas began to differentiate into shoots. Ten weeks after Expt. 1 was initiated, shoots were excised from cotyledons (Fig. 1B) and transferred to secondary medium for further elongation.

Influence of $\mathrm{BA}$ concentration and duration of $\mathrm{H}_{2} \mathrm{O}_{2}$ treatment on shoot induction-Expt. 1. Both BA concentration and duration of $\mathrm{H}_{2} \mathrm{O}_{2}$ treatment significantly influenced shoot production, and a significant interaction resulted (Fig. 2). Regardless of length of exposure to $\mathrm{H}_{2} \mathrm{O}_{2}$, shoot regeneration increased linearly with increased BA concentration, although the degree of increase was affected by length of $\mathrm{H}_{2} \mathrm{O}_{2}$ treatment. Differences between duration of $\mathrm{H}_{2} \mathrm{O}_{2}$ treatment were more pronounced on medium containing low $\left(0.5\right.$ and $1 \mathrm{mg} \cdot \mathrm{liter}^{-1}$, than high levels of BA (5 and $10 \mathrm{mg} \cdot$ liter $\left.^{-1}\right)$. With increased treatment duration (6 to 9 days), shoot proliferation declined more
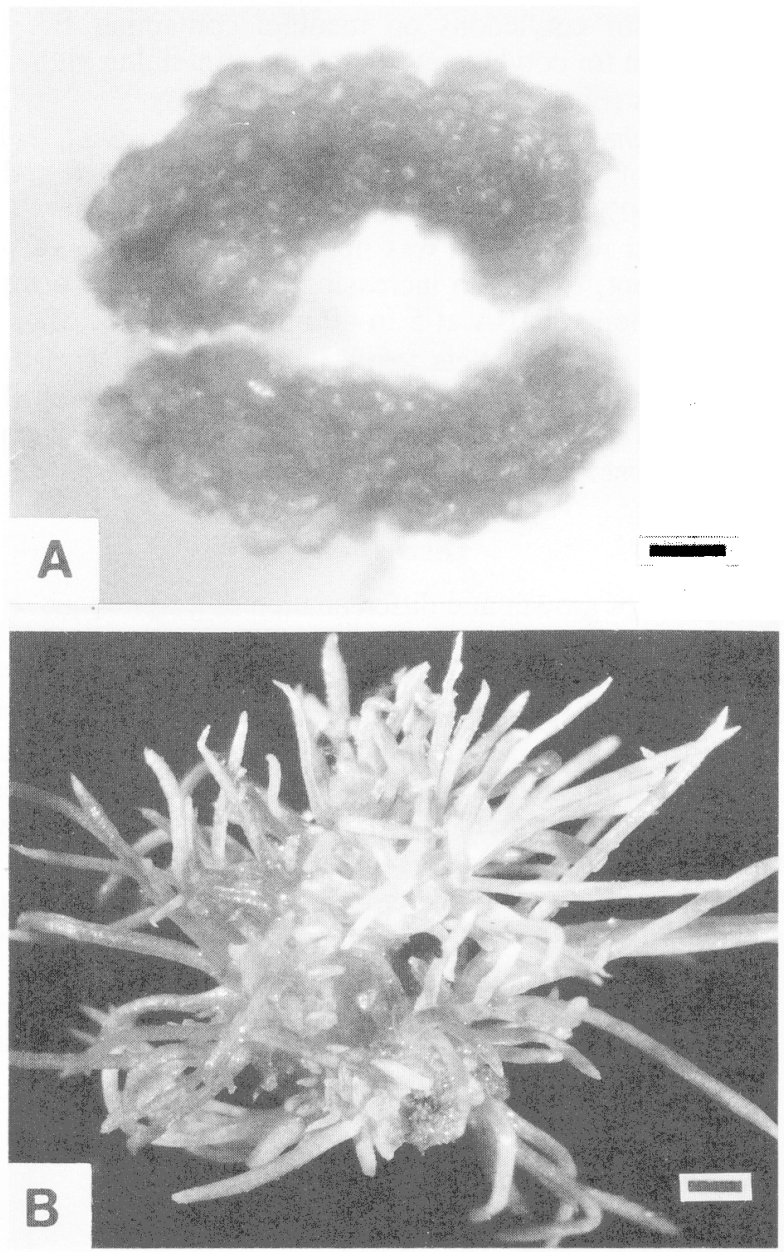

Fig. 1. Stages in tissue culture propagation of Virginia pine. (A) Cotyledons with meristematic areas (scale $=1 \mathrm{~mm}$ ). (B) Cluster of shoots on cotyledon (scale $=1 \mathrm{~mm}$ ).

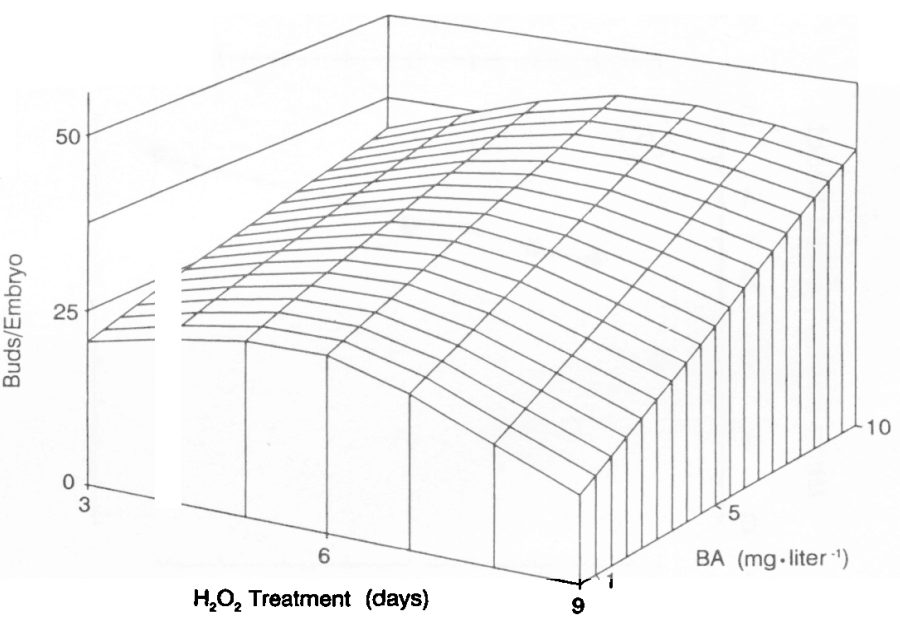

Fig. 2. Influence of duration of $\mathrm{H}_{2} \mathrm{O}_{2}$ treatment (X) and BA concentration $(\mathrm{Z})$ on adventitious shoot formation (Y) on cotyledons of Virginia pine. Data expressed on a per-embryo basis. Response surface predicted from the following equation: $\mathrm{Y}=-1.41+10.03 \mathrm{X}$ $-0.97 \mathrm{X}^{2}+1.07 \mathrm{Z}+0.02 \mathrm{X}^{2} \mathrm{Z}, R^{2}=0.69$. Equation variables were significant at $P<0.07$ or were involved in significant interactions. 
dramatically for cotyledons on medium containing BA at 1 $\mathrm{mg} \cdot$ liter $^{-1}$ than for cotyledons on medium containing higher BA concentrations (Fig. 2).

Rooting of shoots and acclimation of plantlets-Expt. 2. Percent rooting of shoots not treated with IBA was $3 \%$ and increased to $\approx 50 \%$ for concentrations of 5 to $40 \mathrm{mg} \cdot \operatorname{liter}^{-1}$ (Fig. 3A). A similar relationship was noted for the number of roots per rooted shoot, except an increasing linear response occurred for concentrations of IBA at 5 to $40 \mathrm{mg} \cdot$ liter $^{-1}$ Fig. 3B).

After transfer of pantlets to the peat-vermiculite medium, root and shoot growth continued. Plantlets acclimated easily to environmental conditions in the culture room and later to greenhouse conditions, and nearly all survived.

\section{Discussion}

The pattern of growth and differentiation of adventitious shoots on cotyledons of Virginia pine is consistent with reports of other Pinus spp. using cotyledons as explants (Amerson et al., 1988; Franco and Schwarz, 1985; Perez-Bermudez and Sommer, 1987). Changes occur in surface morphology as a result of cytokinin treatment, and upon transfer to a medium lacking cytokinin, shoots develop from meristematic areas (Fig. 1A). Following excision from cotyledons, shoot, elongation continues.

Production of adventitious shoots on cotyledons of Virginia pine was influenced by both BA concentration and duration of
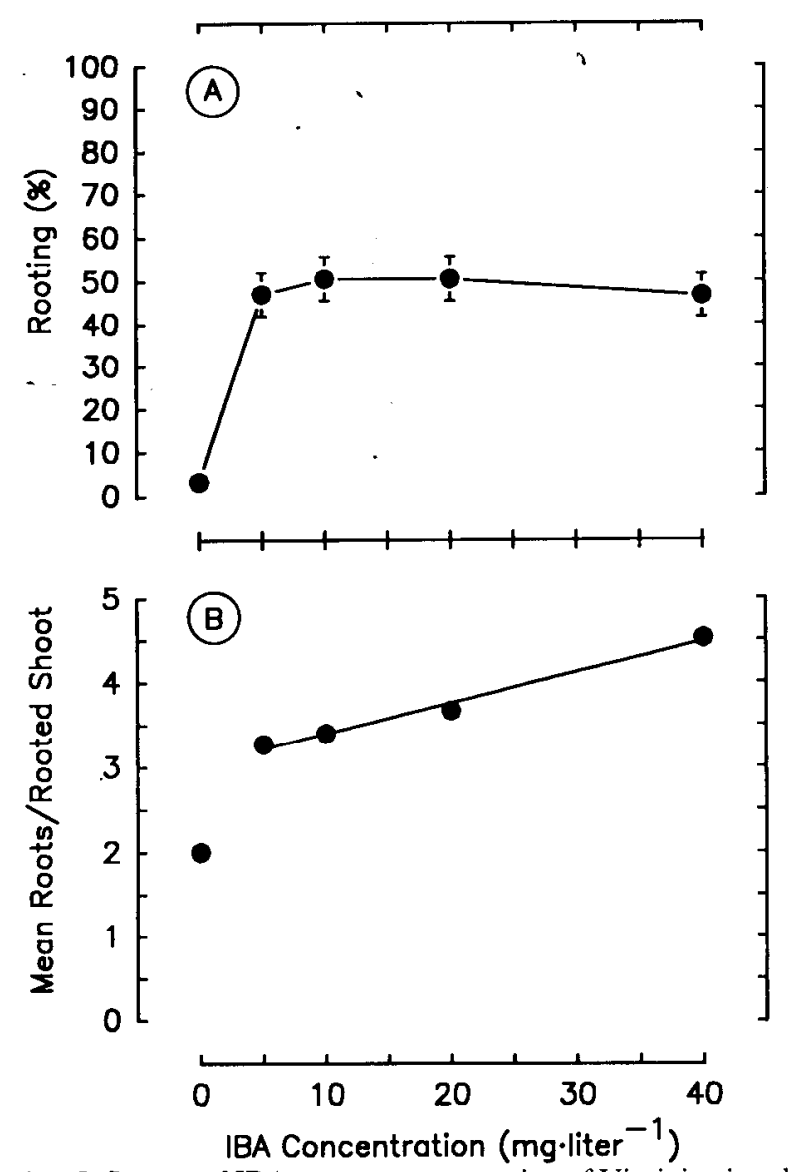

Fig. 3. Influence of IBA treatments on rooting of Virginia pine shoots produced in vitro. (A) Percent rooting; each data point is based on 102 observations. Vertical lines represent \pm 1 SE and were omitted when $<2 \%$. (B) Mean number of roots per rooted shoot; regression model: $\mathrm{Y}=3.04+0.04 \mathrm{X}(5 \leq \mathrm{X} \geq 40 \mathrm{mg}$ IBA/liter $), R^{2}=$ $0.45, P<0.07$.
$\mathrm{H}_{2} \mathrm{O}_{2}$ treatment (Fig. 2). High levels of BA (10 mg.liter $\left.{ }^{-1}\right)$ combined with moderate to long exposures (6 to 9 days) to $\mathrm{H}_{2} \mathrm{O}_{2}$ resulted in greater shoot formation than a shorter exposure (3 days). For low BA concentrations $\left(0.5\right.$ to $\left.1 \mathrm{mg} \cdot \mathrm{liter}^{-1}\right)$, short to moderate treatment times (3 to 6 days) resulted in more shoots than a longer exposure. With a moderate level of BA $\left(5 \mathrm{mg} \cdot \operatorname{liter}^{-1}\right)$, the effect of $\mathrm{H}_{2} \mathrm{O}_{2}$ treatment was less striking. Overall, shoot production was greatest with cotyledons from seeds treated with $\mathrm{H}_{2} \mathrm{O}_{2}$ for 6 days and placed on medium containing $10 \mathrm{mg}$ BA/liter.

Cytokinin concentration and duration of germination also affect the regenerative capacity of other coniferous species in vitro. Pinus spp., including loblolly pine (P. taeda L.) (Mott et al., 1977), Monterey pine (P. radiata D. Don) (Thorpe, 1988), Calabrian pine (P. brutia Ten.) (Abdullah and Grace, 1987), and Caribbean pine ( $P$. caribaea Morlet) (Webb and Santiago, 1983), exhibit a similar response, although optimum cytokinin concentration and germination time vary with species.

Shoot regeneration of Virginia pine increased with increasing BA concentration (Fig. 2). Shoot production was greatest on medium containing BA at $10 \mathrm{mg} \cdot \operatorname{liter}^{-1}$. Although shoot lengths were not recorded at the time of excision from cotyledons, shoots were shorter and more difficult to handle than those at lower BA concentrations. Since BA concentrations $>10 \mathrm{mg} \cdot \mathrm{liter}^{-1}$ result in stunted shoots for other species of pines, higher concentrations were not tested (Biondi and Thorpe, 1982; von Arnold and Eriksson, 1981).

Although IBA was beneficial in stimulating both percent rooting and number of roots formed (Fig. 3), there is still room for improvement. This is particularly evident for rooting percentage, since only $50 \%$ of shoots treated with 5 to $40 \mathrm{mg}$ IBA/liter rooted. Use of other auxins, alone or in combination with IBA, or ex vitro rooting might lead to a greater response. Combinations of auxins have proven more beneficial for such species as Douglas fir, Monterey pine, Norway spruce [Picea abies (L.) Karst], and pitch pine (Pinus rigidia D. Don) (Mohammed and Vidaver, 1988). Also, different environmental conditions may enhance rooting. Gasper and Coumans (1987) noted that reduced irradiance promotes root initiation, and high temperatures (30C) aid initiation of root primordia, whereas lower temperatures $(25 \mathrm{C})$ support root elongation.

We have shown that Virginia pine can be propagated by in vitro techniques. Methods described herein are similar to those reported for other Pinus spp. using cotyledons as explants. Although basic procedures for tissue culture propagation of pines are similar, some differences exist. For example, our results indicate that the highest shoot production of Virginia pine occurred using $10 \mathrm{mg} \mathrm{BA} /$ liter, whereas Abdullah et al. (1985) reported $3 \mathrm{mg} \cdot \mathrm{liter}^{-1}$ to be optimum for Calabrian pine. The response, however, of explants to $\mathrm{BA}$ and $\mathrm{H}_{2} \mathrm{O}_{2}$ treatment might vary depending on seed age and provenance and is worthy of further study.

\section{Literature Cited}

Abdullah, A.A. and J. Grace. 1987. Regeneration of Calabrian pine from juvenile needles. Plant Sci. 53:147-155.

Abdullah, A.A., M.M. Yeoman, and J. Grace. 1985. In vitro adventitious shoot formation from embryonic and cotyledonary tissues of Pinus brutia Ten. Plant Cell Tissue Organ Culture 5:35-44.

Amerson, H.V., L.J. Framptom, Jr., S.E. McKeand, R.L. Mott, and R.J. Weir. 1985. Loblolly pine tissue culture: Laboratory, greenhouse, and field studies, p. 271-288. In: R.R. Henke, K.W. Hughs, M.J. Constantin, and A. Hollaender (eds.). Tissue culture in forestry and agriculture. Plenum Press, New York.

Amerson, H.V., L.J. Framptom, Jr., R.L. Mott, and P.C. Spaine. 
1988. Tissue culture of conifers using loblolly pine as a model, p. 117-137. In: J. Hanover and D. Keathley (eds.). Genetic manipulation of woody plants. Plenum, New York.

Biondi, S. and T.A. Thorpe. 1982. Growth regulator effects, metabolic changes, and respiration during shoot initiation in cultured cotyledon explants of Pinus radiata. Bot. Gaz. 143:20-25.

Bonga, J.M. and D.J. Durzan. 1987. Cell and tissue culture in forestry. vol. 3. Martinus Nijhoff, Boston.

Brown, C.L. and H.E. Sommer. 1977. Bud and root differentiation in conifer cultures. Technical Assn. Pulp \& Paper Ind. 60:72-73.

France, E.O. and O.J. Schwarz. 1985. Micropropagation of two tropical conifers: Pinus oocarpa Schiede and Cupressus lusitanica Miller, p. 195-214. In: R.R. Henke, K.W. Hughs, M.J. Constantine, and. A. Hollaender (eds.). Tissue culture in forestry and agriculture. Plenum, New York.

Gasper, T. and M. Coumans. 1987. Root formation, p. 202-217. In: J.M. Bongs and D.J. Durzan (eds.). Cell and tissue culture in forestry. vol. 2. Martinus Nijhoff, Boston.

Hoagland, D.R. and D.I. Arnon. 1950. The water-culture method for growing plants without soil. California Agr. Expt. Sta. Circ. 347.

Mohammed, G.H. and W.E. Vidaver. 1988. Root production and plantlet development in tissue-cultured conifers. Plant Cell Tissue Organ Culture 14:137-160.

Mott, R.L. and H.V. Amerson. 1981. A tissue culture process for the clonal production of loblolly pine plantlets. North Carolina Agr. Res. Serv. Tech. Bul. 271.

Mott, R.L., R.H. Smeltzer, and A. Mehra-Palta. 1977. An anatomical and cytological perspective on pine organogenesis in vitro. Proc. Technical Assn. Pulp \& Paper Ind. For. Biol./Wood Chem. Conf., Madison, Wis. p. 9-14.

Perez-Bermudez, P. and H.E. Sommer. 1987. Factors affecting bud induction in Pinus elliottii (Engelm,) embryos cultured in vitro. Plant Cell Tissue Organ Cult. 11:25-35.

Thorpe, T.A. 1988. Physiology of bud induction in conifers in vitro, p. 167-183. In: J. Hanover and D. Keathley (eds.). Genetic manipulation of woody plants. Plenum, New York.

von Arnold, S. and T. Eriksson. 1981. In vitro studies of adventitious shoot formation in Pinus contorta. Can. J. Bot. 59:870-874.

Webb, D.T. and O.D. Santiago. 1983. Cytokinin induced bud formation on Caribbean pine (Pinus caribaea Morlet) embryos in vitro. Plant Sci. Lett. 32:17-21. 